\title{
An efficient one-pot access to trithiocarbonate-tethered peptidomimetics
}

\author{
N. Narendra, H. S. Lalithamba, Vommina V. Sureshbabu* \\ Peptide Research Laboratory, Department of Studies in Chemistry, Central College Campus, Bangalore University, Dr. B.R. Ambedkar Veedhi, Bangalore University,
} Bangalore 560 001, India

\section{A R T I C L E I N F O}

Article history:

Received 2 July 2010

Revised 15 September 2010

Accepted 19 September 2010

Available online 24 September 2010

Keywords:

Peptidomimetics

Amino alkyl thiols

Carbon disulfide

Trithiocarbonates

\begin{abstract}
A B S T R A C T
A simple protocol for the synthesis of a new class of trithiocarbonate-linked peptidomimetics and neoglycosylated amino acids is described. N-Protected amino alkyl thiols were treated with $\mathrm{CS}_{2}$ in the presence of triethylamine (TEA) to generate trithiocarbonate salt, which upon reaction with appropriate halides afforded dipeptidomimetics in good yields. Further, the procedure was also extended for the synthesis of $N, N^{\prime}$-orthogonally protected trithiocarbonate-linked dipeptidomimetics.
\end{abstract}

(c) 2010 Elsevier Ltd. All rights reserved.
Peptides are attractive targets for drug discovery because of their high affinity and specificity towards biological functions. However, the poor in vivo stability, inadequate pharmacokinetic properties and low bioavailability ${ }^{1}$ have generally limited their broader utility. In this context, a variety of peptide mimics are being developed by introducing a plethora of structural motifs as replacement to the native peptide bond with the objective of improving the activity of peptide based drugs. ${ }^{2}$ Our group previously had reported efficient methods for the synthesis of peptidomimetics containing unnatural linkages such as retro-amide, urea, carbamate, heterocycles, and dithiocarbamate moieties as peptide bond surrogates. ${ }^{3}$ In continuation of this work, we have now focused our attention toward the synthesis of hitherto unreported class of peptidomimetics containing trithiocarbonate linkage.

Trithiocarbonate compounds possess a wide range of applications. For instance, they act as therapeutic agents such as inhibitors of histone deacetylases (HDAC) in the treatment of cancer, ${ }^{4}$ and as pesticides and insecticides. ${ }^{5}$ In organic synthesis, these compounds are employed as reversible addition fragmentation chain-transfer agents (RAFT) in radical polymerization ${ }^{6}$ and as key precursors for the preparation of a number of compounds like trithiocarbonate-S-oxides, ${ }^{7}$ thiols, ${ }^{8}$ olefins, ${ }^{9}$ thioacetates, ${ }^{10}$ and derivatives of dicarbonyldithiocarboxylate. ${ }^{11}$ They have also been employed as a protection for thiol functionality ${ }^{12}$ and as useful compounds in the growing arsenal of nanotechnology in surface and colloidal science. $^{13}$

\footnotetext{
* Corresponding author. Tel.: +91 082296 1339; mobile: +91 09986312937.

E-mail addresses: sureshbabuvommina@rediffmail.com, hariccb@gmail.com, hariccb@hotmail.com (V.V. Sureshbabu).
}

Earlier approaches for the synthesis of trithiocarbonates employed the reaction of thiols with chlorodithioformates ${ }^{14}$ or thiophosgene. ${ }^{15}$ Another method for their preparation includes the dialkylation of trithiocarbonate anion with halides using a phasetransfer catalyst or thermal assistance. ${ }^{16}$ Other alternative routes for their synthesis include the reaction of sodium trithiocarbonates with epoxides, ${ }^{17}$ reaction of metal xanthates with episulfides, ${ }^{18}$ or the reaction of thiol with $\mathrm{CS}_{2}$ in the presence of $\mathrm{KOH}$ under phase transfer catalyst to form potassium trithiocarbonate followed by subsequent reaction with an alkyl halide. ${ }^{5}$ Wood et al. reported the synthesis of symmetrical trithiocarbonates starting from primary thiols using 1,1'-thiocarbonyldiimidazole (TCDI). ${ }^{6}$ Trithiocarbonates syntheses by S-arylation of potassium carbonotrithioates with diaryliodonium salts were developed by Wang et al. ${ }^{19}$ They have also been prepared by a one-pot reaction of alkyl halides with $\mathrm{CS}_{2}$ in the presence of $\mathrm{Cs}_{2} \mathrm{CO}_{3},{ }^{20} \mathrm{KF} / \mathrm{Al}_{2} \mathrm{O}_{3},{ }^{21}$ or tetra- $n$-butylammonium hydroxide (TBAH). ${ }^{22}$ It was recently described that symmetrical and unsymmetrical trithiocarbonates can be prepared from $\mathrm{CS}_{2}$, thiol, and alkyl halide in the presence of TEA in water at room temperature in one-pot. ${ }^{23}$ Chaturvedi et al. demonstrated a onepot, three component coupling of thiols with $\mathrm{CS}_{2}$ using Mitsunobu reagent at room temperature. ${ }^{24}$

However, in spite of the wide spread importance of trithiocarbonates, their insertion into peptide back bone is yet to be reported. The properties of trithiocarbonate linkage to act as peptide bond surrogate and its biological and conformational consequences have not been studied in detail yet. However in the available reports, it has been shown that a trithiocarbonate group in $\alpha$-position to the carbonyl group (a subunit present in the title trithiocarbonate-linked petidomimetics) constitutes a new head group for HDAC inhibitors. ${ }^{4,25 a}$ In this case, the trithiocarbonate 
moiety is a substitution to the well-known benzamide and hydroxamate groups in HDAC inhibitors. Besides, the trithiocarbonate ion itself has shown to mimic the sulfonamide and urea (moieties frequently used as peptide bond surrogates) binding to the carboxy anhydrase enzyme. ${ }^{25 \mathrm{~b}}$ Regarding the conformation of the dialkyl trithiocarbonates, it has been shown through low temperature ${ }^{1} \mathrm{H}$ NMR studies that in case of dimethyl trithiocarbonate, the $E, Z$ and $E, E$ conformations are present in 0.52:0.48 ratio. ${ }^{25 c}$ $\mathrm{X}$-ray crystallographic studies of monoalkyl trithiocarbonates and several organometallic compounds containing trithiocarbonate ligands have been carried out. ${ }^{25 d}$ With the rapid progress made in the area of peptidomimetics, synthetic studies on such novel compounds would result in interesting molecules with biological advantages. This Letter describes a simple synthesis of trithiocarbonate-linked peptidomimetics employing a reaction between $\mathrm{CS}_{2}$, a N-protected amino alkyl thiol and an amino acid derived alkyl halide in the presence of TEA. According to established mechanism, the thiol and $\mathrm{CS}_{2}$ react initially in the presence of TEA to generate a triethylamine salt of corresponding trithiocarbonate, which then react with alkyl halide to furnish the trithicarbonate compound. ${ }^{5}$

Our primary targets were dipeptidomimetics of the type 4 (Scheme 1 and Table 1 ) which were accessed by employing a $\mathrm{N}$-protected amino alkyl thiol, $\mathrm{CS}_{2}$, TEA and bromomethyl ester. The Fmoc/Z-protected amino alkyl thiols 1 were prepared according to the protocol recently reported by us. Briefly, the N-protected amino acids were converted to respective alkyl iodides via the established procedure and then refluxed with thiourea in acetone to yield isothiouronium salt. This intermediate was hydrolyzed with aqueous sodium pyrosulfite to afford corresponding thiol. ${ }^{26}$ On the other hand, $\alpha$-bromo esters 2 were prepared through diazotization of the corresponding amino acid in the presence of $\mathrm{KBr}$ followed by esterification using $\mathrm{CH}_{3} \mathrm{OH}$ and $\mathrm{SOCl}_{2}{ }^{27}$

Having the amino acid derived halide and thiol components in hand, we next proceeded toward the synthesis of title molecules. In a typical experiment, Fmoc-Phe- $\psi\left[\mathrm{CH}_{2}-\mathrm{SH}\right]$ in THF was treated with $\mathrm{CS}_{2}$ and TEA, followed by the addition of a solution of $\mathrm{BrCH}\left(\mathrm{CH}_{2} \mathrm{C}_{6} \mathrm{H}_{5}\right) \mathrm{COOMe}$ in $\mathrm{CH}_{2} \mathrm{Cl}_{2}$. The reaction was complete in about $5 \mathrm{~h}$, as monitored by TLC. A simple work-up followed by column chromatography yielded pure N-protected trithiocarbonatelinked dipepetidomimetic $4 \mathbf{c}$ in $80 \%$ yield (Scheme 1 ). ${ }^{28}$ The generality of this protocol was demonstrated by synthesizing a series of dipeptidomimetics (4a-h) in good yield and purity, employing several Fmoc/Z-amino alkyl thiols and bromomethyl esters.

It is well known that the thiolysis/alcoholysis of chiral $\alpha$-bromo alkyl esters proceed through $\mathrm{S}_{\mathrm{N}} 2$ mechanism leading to the inversion of configuration at the asymmetric carbon. Yang et al. during their work on $\alpha$-aminoxy esters that involved a reaction between bromo ester and $\mathrm{Cbz}-\mathrm{NHOH}$ obtained the inverted product in
92-94\% yield. ${ }^{27}$ Similarly Paladino et al. have observed that during the coupling of $\alpha$-bromo acids with thiols, inversion of configuration at the bromo derivative occurs to a large extent. ${ }^{29}$ On this basis, it is reasonable to understand that in the present study, in the dipeptidomimetics $\mathbf{4 c - g}$ synthesized starting from $\mathrm{L}-\alpha$-bromo esters, the chiral carbon $\alpha$ to ester group will be of D-configuration due to inversion during the reaction. The HPLC of crude samples of $4 \mathbf{e}$ and $4 \mathbf{f}$ prepared through reacting Fmoc-Phe- $\psi\left[\mathrm{CH}_{2}-\mathrm{SH}\right]$ with the bromo esters obtained from L- and D-Ala, respectively revealed the presence of diastereomers in 93:7 and 94:6 ratio respectively. Further, the 1:1 mixture of $\mathbf{4 e}$ and $\mathbf{4 f}$ had two well separated peaks at $R_{\mathrm{t}}$ values corresponding to each isomer. ${ }^{30}$ The major isomers in the crude samples correspond to the products resulting from inversion.

In the next stage, the chain extension of the dipeptidomimetic 4 on $\mathrm{N}$-terminus was undertaken. Starting with $\mathbf{4 a}$, the amine was deprotected using $60 \%$ diethylamine (DEA) in dry $\mathrm{CH}_{2} \mathrm{Cl}_{2}$ and the resulting free amino dipeptidomimetic was coupled with an $\mathrm{N}$-protected amino acid $\mathbf{5}$ via the mixed anhydride method to obtain trithiocarbonate bearing tripeptidomimetic $\mathbf{6}$ (Scheme 2).

Recently there has been a surge in the interest in the synthesis of neoglycosylated amino acids in which the native linkage between the carbohydrate and amino acid segments is replaced with unnatural ones. This is because of the finding that glycosylation of peptides increases the absorption of poorly bio-available peptides by increasing their membrane permeability. ${ }^{31 a}$ With our interest in such class of molecules, the present protocol was extended to prepare a set of trithiocarbonate-linked neoglycosylated amino acids as well. Toward this end, a reaction between N-protected amino alkyl thiol and sugar bromide was undertaken. Starting with D-galactose, the required 2,3,4,6-tetra- $O$-acetyl- $\beta$-D-glucopyranosyl bromide 3 was prepared employing well established procedure. ${ }^{31 \mathrm{~b}}$ Further, a solution of $\mathbf{1}$ was reacted with $\mathbf{3}$ in the presence of $\mathrm{CS}_{2}$ and TEA to yield trithiocarbonate-linked $\mathrm{N}$-protected amino alkyl glycosides (4i-k). All the products were isolated as pure samples and characterized by ${ }^{1} \mathrm{H}$ NMR, ${ }^{13} \mathrm{C}$ NMR and mass analyses.

Finally, the current protocol was extended to synthesize $N$, $N^{\prime}$-orthogonally protected trithiocarbonate-linked dipeptidomimetics by replacing the bromomethyl ester in the above mentioned protocol with N-protected amino alkyl halides. Starting with an N-protected amino alkyl thiol 1, the triethylamine salt of corresponding trithiocarbonate intermediate $\mathbf{7}$ was generated via the reaction with $\mathrm{CS}_{2}$ in presence of TEA which without isolation was treated with $\mathrm{N}$-protected amino alkyl iodide $\mathbf{8}$ to yield trithiocarbonate-linked orthogonally protected dipeptidomimetics $9 \mathrm{a}-\mathbf{g}$ (Scheme 3 and Table 2 ) in excellent yield. The reaction was complete in about $6 \mathrm{~h}$. All the compounds were isolated after a simple work-up as yellow colored compounds and fully characterized. $^{32}$

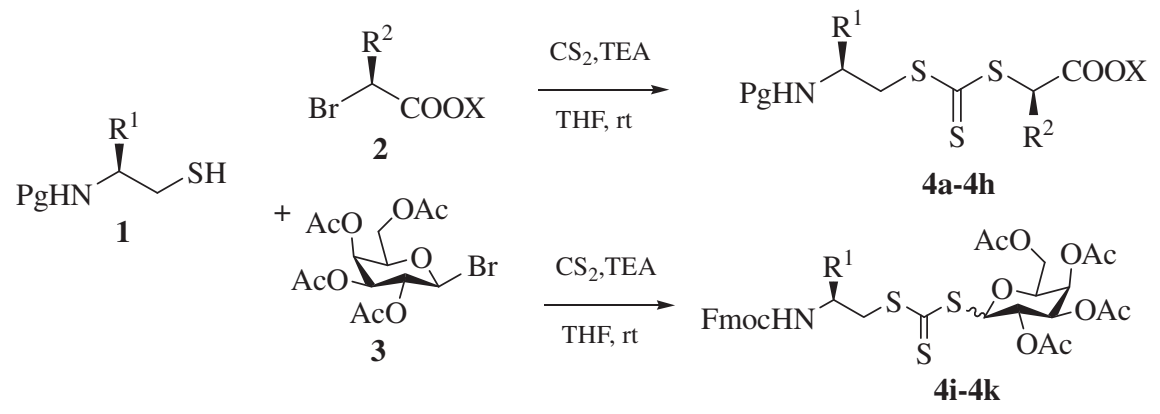

$\mathrm{Pg}=$ Fmoc or $\mathrm{Z}$ group,$\quad \mathrm{X}=$ Methyl or Ethyl group

Scheme 1. Synthesis of trithiocarbonates $\mathbf{4 a - k}$. 
Table 1

List of trithiocarbonate tethered peptidomimetics 4

\begin{tabular}{|c|c|c|c|c|}
\hline Compd No. & Trithiocarbonate & {$[\alpha]_{\mathrm{D}}^{25}\left(c 1, \mathrm{CHCl}_{3}\right)$} & Yield (\%) & $\begin{array}{l}\text { HRMS } \\
\text { obsd/calcd }\end{array}$ \\
\hline $4 a$ & Fmoc & 12.5 & 79 & $\begin{array}{l}484.0690 \\
(484.0687)\end{array}$ \\
\hline $4 b$ & Fmocr & 22.0 & 83 & $\begin{array}{l}526.1150 \\
(526.1156)\end{array}$ \\
\hline $4 c$ & Fmoc & 27.0 & 80 & $\begin{array}{l}650.1467 \\
(650.1469)\end{array}$ \\
\hline 4d & Fmoc & 17.0 & 88 & $\begin{array}{l}662.1508 \\
(662.1503)\end{array}$ \\
\hline $4 e$ & Fmoc & 13.9 & 81 & $\begin{array}{l}574.1159 \\
(574.1156)\end{array}$ \\
\hline $4 f$ & Fmoc & 23.6 & 80 & $\begin{array}{l}574.1158 \\
(574.1156)\end{array}$ \\
\hline $4 \mathrm{~g}$ & $\mathrm{ZHN}$ & 13.6 & 81 & $\begin{array}{l}305.9850 \\
(305.9853)\end{array}$ \\
\hline $4 h$ & & 8.2 & 82 & $\begin{array}{l}322.0133 \\
(322.0132)\end{array}$ \\
\hline $4 \mathbf{i}$ & Fmo & 22.3 & 76 & $\begin{array}{l}742.1420 \\
(742.1426)\end{array}$ \\
\hline $4 \mathbf{j}$ & Fmoc & 28.1 & 79 & $\begin{array}{l}770.1731 \\
(770.1739)\end{array}$ \\
\hline $4 k$ & Fmo & 19.2 & 75 & $\begin{array}{l}784.1890 \\
(784.1896)\end{array}$ \\
\hline
\end{tabular}

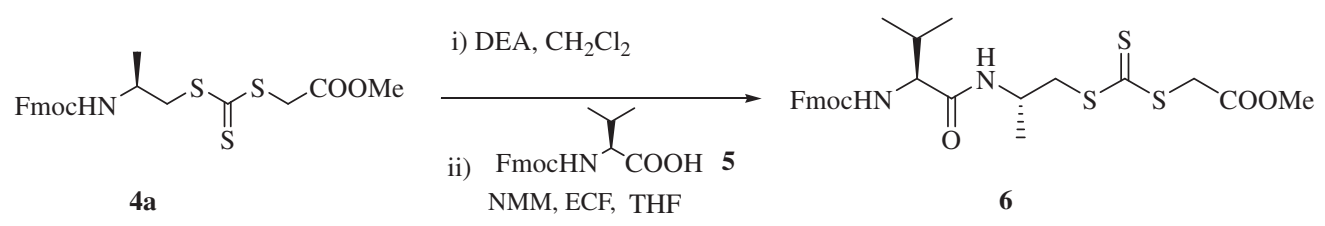

Scheme 2. Synthesis of trithiocarbanate-linked tripeptidomimetic 6 through N-terminal elongation.

In summary, we have demonstrated a facile and efficient method for the synthesis of a new class of trithiocarbonate-linked pepti- domimetics. The reaction is rapid, high yielding, and free from toxic reagents. All the compounds were isolated and fully characterized. 


$$
\operatorname{Pg}^{1}=\mathrm{Pg}^{2}=\text { Fmoc or } \mathrm{Z} \text { group }
$$

Scheme 3. Synthesis of trithiocarbonate-linked orthogonally protected dipeptidomimetics.

Table 2

List of trithiocarbonate-linked orthogonally protected dipeptidomimetics $\mathbf{9}$

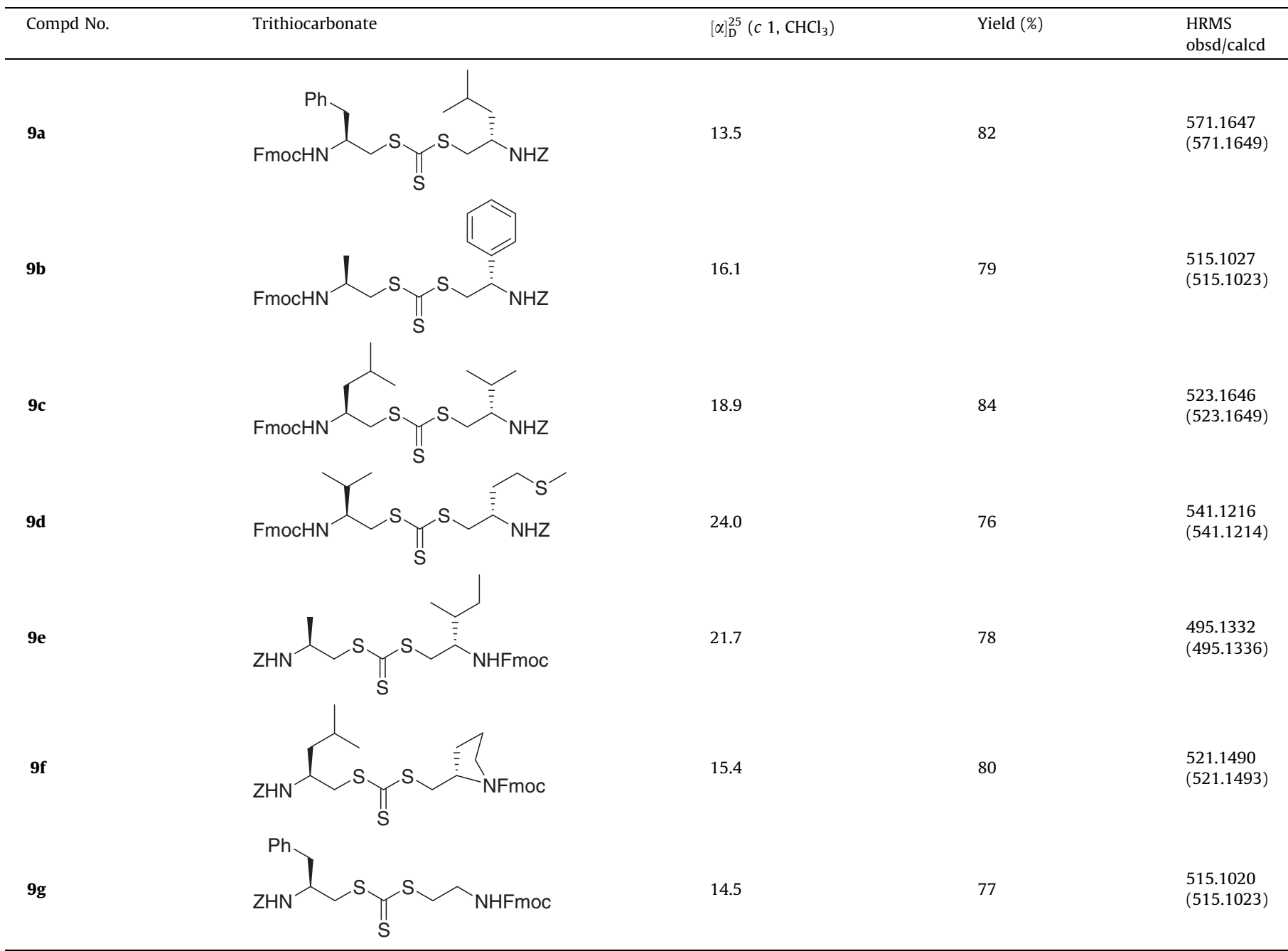

\section{Acknowledgments}

Authors thank the University Grants Commission (Grant No. 3779/2009), Govt. of India, New Delhi for the financial assistance. HSL thanks Siddaganga Institute of Technology, Tumkur for a research leave.

\section{References and notes}

1. Pseudo-Peptides in Drug Discovery; Nielsen, P. E., Ed.; Wiley-VCH: Germany, 2004.

2. (a)Synthesis of peptides and peptidomimetics (Houben-Weyl): Goodman, M., Felix, A., Moroder, L., Toniolo, C., Eds.Georg Thieme; Stuttgart: Germany, 2003; Vol. E22c,. and references cited therein (b) Boeijen, A.; van Ameijde, J.; Liskamp, R. M. J. J. Org. Chem. 2001, 66, 8454-8462.
3. Hemantha, H. P.; Sureshbabu, V. V. Tetrahedron Lett. 2009, 50, 7062-7066. and references cited therein.

4. Dehmel, F.; Weinbrenner, S.; Julius, H.; Ciossek, T.; Maier, T.; Stengel, T.; Fettis, K.; Burkhardt, C.; Wieland, H.; Beckers, T. J. Med. Chem. 2008, 51, 3985-4001.

5. Degani, I.; Fochi, R.; Gatti, A.; Regondi, V. Synthesis 1986, 894-899. and references cited therein.

6. Wood, M. R.; Duncalf, D. J.; Rannard, S. P.; Perrier, S. Org. Lett. 2006, 8, 553-556

7. Leriverend, C.; Metzner, P.; Capperucci, A.; Degl'Innocenti, A. Tetrahedron 1997 $53,1323-1342$

8. Martin, D. J.; Greco, C. C. J. Org. Chem. 1968, 33, 1275-1276.

9. Corey, E. J.; Carey, F. A.; Winter, R. A. E. J. Am. Chem. Soc. 1965, 87, 934-935.

10. Jordis, U.; Rudolf, M. Phosphorus, Sulfur Silicon Relat. Elem. 1984, 19, 279-283.

11. Oliva, A.; Molinari, A.; Sanchez, L. Synth. Commun. 1998, 28, 3381-3386.

12. Wuts, P. G. M.; Greene, T. W. Protecting Groups in Organic Synthesis; John Wiley \& Sons: New York, 2006.

13. Efrima, S.; Pradhan, N. C.R. Chimie 2003, 6, 1035-1045.

14. Godt, H. C.; Wann, R. E. J. Org. Chem. 1961, 26, 4047-4051.

15. Duus, F.. In Comprehensive Organic Chemistry; Barton, D., Ollis, W. D., Eds.; Pergamon: New York, 1979; Vol. 3, p 432. 
16. Leung, M.-K.; Hsieh, D.-T.; Lee, K.-H.; Liou, J.-C. J. Chem. Res., Synop. 1995, 478479.

17. Saeed, M.; Abbas, M.; Abdel-Jalil, R. J.; Zahid, M.; Voelter, W. Tetrahedron Lett. 2003, 44, 315-317.

18. Creighton, A. M.; Owen, L. N. J. Chem. Soc. 1960, 1024-1029.

19. Wang, F.-Y.; Chen, Z.-C.; Zheng, Q.-G. J. Chem. Res., Synop. 2003, 810-811.

20. Aoyagi, N.; Ochiai, B.; Mori, H.; Endo, T. Synlett 2006, 636-638.

21. Movassagh, B.; Soleiman-Beigi, M.; Nazari, M. Chem. Lett. 2008, 37, 22-23.

22. Soleiman-Beigi, M.; Arzehgar, Z.; Movassagh, B. Synthesis 2010, 392-394.

23. Movassagh, B.; Soleiman-Beigi, M. Monatsh. Chem. 2008, 139, 927-930.

24. Chaturvedi, D.; Chaturvedi, A. K.; Mishra, N.; Mishra, V. Tetrahedron Lett. 2008 $49,4886-4888$.

25. (a) Dehmel, F.; Ciossek, T.; Maier, T.; Weinbrenner, S.; Schmidt, B.; Zoche, M.; Beckers, T. Bioorg. Med. Chem. Lett. 2007, 17, 4746-4752; (b) Temperini, C. Scozzafava, A.; Supuran, C. T. Bioorg. Med. Chem. Lett. 2010, 20, 474-478; (c) Garahi, M.; Badelle, F.; Noe, E. A. J. Org. Chem. 1987, 52, 3941-3944; (d) Yekeler, H.; Yekeler, M. Appl. Surf. Sci. 2004, 236, 435-443.

26. Sureshbabu, V. V.; Vishwanatha, T. M.; Vasantha, B. Synlett 2010, 1037-1042.

27. Yang, D.; Li, B.; Ng, F.-F.; Yan, Y.-L.; Qu, J.; Wu, Y.-D. J. Org. Chem. 2001, 66, 7303-7312.

28. Typical procedure for the synthesis of trithiocarbonate-linked dipeptidomimetics 4c: To a solution of $N$-Fmoc-Phe $\psi\left[\mathrm{CH}_{2}-\mathrm{SH}\right](2.5 \mathrm{mmol})$ in THF $(5 \mathrm{~mL})$ and $\mathrm{CS}_{2}$ $(3 \mathrm{~mL})$ was added TEA $(3.75 \mathrm{mmol})$. After $20 \mathrm{~min}$, a solution of $\mathrm{BrCH}\left(\mathrm{CH}_{2} \mathrm{C}_{6} \mathrm{H}_{5}\right) \mathrm{COOMe}(2.5 \mathrm{mmol})$ in $\mathrm{CH}_{2} \mathrm{Cl}_{2}$ was added and the reaction mixture was continued to stir for $5 \mathrm{~h}$. After completion of the reaction (TLC), it was evaporated under vacuum and the crude was taken into ethyl acetate $(15 \mathrm{~mL})$. The organic layer was washed with citric acid solution $(10 \%, 10 \mathrm{~mL})$ water and brine. After drying over sodium sulfate, the organic phase was concentrated and the crude was purified through column chromatography using EtOAc in hexane as eluent.

29. Paladino, J.; Thurieau, C.; Morris, A. D.; Kucharczyk, N.; Rouissi, N.; Regoli, D.; Fauchere, J.-L. Int. J. Pept. Protein Res. 1993, 42, 284-293.
30. Samples $\mathbf{4 e}$ and $\mathbf{4 f}$ eluted at $R_{\mathrm{t}}$ values 22.6 and $23.9 \mathrm{~min}$, respectively, while the equimolar mixture of these diastereomers had two distinct peaks at $R_{\mathrm{t}} 22.7$ and $23.8 \mathrm{~min}$. (HPLC particulars: Agilent 1100 series having G1311A VWD at $\lambda=254 \mathrm{~nm}$, flow $0.50 \mathrm{~mL} / \mathrm{min}$, Column: Agilent Eclipse XDB-C18, pore size $5 \mu \mathrm{m}$, diameter $\times$ length $=4.6 \times 150 \mathrm{~mm}$; method: gradient $0.1 \%$ TFA wateracetonitrile; acetonitrile $30-70 \%$ in $30 \mathrm{~min}$ ).

31. (a) Salvador, L. A.; Elofsson, M.; Kihlberg, J. Tetrahedron Lett. 1995, 51, 56435656; (b) Furniss, B. S.; Hannaford, A. J.: Smith, P. W. G.; Tatchell, A. R. Vogel's Textbook of Practical Organic Chemistry, 5th ed.; Addison Wesley Longman Ltd.: London, 1989.

32. Spectral data for selected compounds: Compound $\mathbf{4 b}:{ }^{1} \mathrm{H}$ NMR $\left(400 \mathrm{MHz}, \mathrm{CDCl}_{3}\right)$ : $\delta 0.95(\mathrm{~d}, 6 \mathrm{H}, J=6.0 \mathrm{~Hz}), 1.25(\mathrm{t}, 3 \mathrm{H}, J=5.2 \mathrm{~Hz}), 1.88(\mathrm{~m}, 1 \mathrm{H}), 3.62(\mathrm{~d}, 2 \mathrm{H}$ $J=4.7 \mathrm{~Hz}), 3.81(\mathrm{~m}, 1 \mathrm{H}), 4.13-4.46(\mathrm{~m}, 7 \mathrm{H}), 4.81(\mathrm{br}, 1 \mathrm{H}), 7.29-7.76(\mathrm{~m}, 8 \mathrm{H})$; ${ }^{13} \mathrm{C} \mathrm{NMR}\left(100 \mathrm{MHz}, \mathrm{CDCl}_{3}\right): \delta 14.0,18.1,32.2,38.7,40.0,47.3,55.6,62.0,66.6$, $119.9,125.0,127.0,127.6,141.3,143.8,156.0,167.1,170.4$

Compound 4c: ${ }^{1} \mathrm{H}$ NMR $\left(400 \mathrm{MHz}, \mathrm{CDCl}_{3}\right): \delta 2.89-2.98(\mathrm{~m}, 1 \mathrm{H}), 3.09(\mathrm{~m}, 1 \mathrm{H})$ 3.10-3.25 (m, $4 \mathrm{H}), 3.61(\mathrm{~s}, 3 \mathrm{H}), 4.15(\mathrm{~m}, 2 \mathrm{H}), 4.35(\mathrm{~d}, 2 \mathrm{H}, J=4.0 \mathrm{~Hz}), 4.48(\mathrm{t}, 1 \mathrm{H}$, $J=6.4 \mathrm{~Hz}), 5.04(\mathrm{br}, 1 \mathrm{H}), 7.17-7.75(\mathrm{~m}, 18 \mathrm{H}) ;{ }^{13} \mathrm{C} \mathrm{NMR}\left(100 \mathrm{MHz}, \mathrm{CDCl}_{3}\right): \delta$ $37.5,40.1,40.5,47.2,52.3,52.7,53.4,71.2,125.6,126.9,127.0,127.1,127.6$, $128.4,128.5,128.6,129.0,129.3,136.7,139.2,141.3,143.8,155.5,170.2,174.5$ Compound 6: ${ }^{1} \mathrm{H}$ NMR (400 MHz, $\left.\mathrm{CDCl}_{3,}\right): \delta 0.95(\mathrm{~d}, 6 \mathrm{H}, J=4.6 \mathrm{~Hz}), 1.10(\mathrm{~d}, 3 \mathrm{H}$, $J=6.2 \mathrm{~Hz}), 2.91(\mathrm{~m}, 1 \mathrm{H}), 3.24(\mathrm{~d}, 2 \mathrm{H}, J=4.2 \mathrm{~Hz}), 3.91(\mathrm{~s} .3 \mathrm{H}), 4.0(\mathrm{~s}, 2 \mathrm{H}), 4.23(\mathrm{~m}$, $1 \mathrm{H}), 4.30(\mathrm{~m}, 1 \mathrm{H}), 4.41(\mathrm{t}, 1 \mathrm{H}, J=4.32 \mathrm{~Hz}), 4.72(\mathrm{~d}, 2 \mathrm{H}, J=5.2 \mathrm{~Hz}), 5.03(\mathrm{br}, 2 \mathrm{H})$ 7.15-74 (m, 8H); ${ }^{13} \mathrm{C}$ NMR $\left(100 \mathrm{MHz}, \mathrm{CDCl}_{3}\right): \delta 17.4,20.1,32.1,39.9,40.2,45.5$, $48.2,51.2,61.9,67.7,126.8,127.9,128.4,128.9,140.1,143.6,156.1,169.2$, 170.3, 175.2.

Compound 9e: ${ }^{1} \mathrm{H}$ NMR (400 MHz, $\mathrm{CDCl}_{3}$ ): $\delta$ 0.85-0.86 (m, 6H), 1.10-1.17 (m, $5 \mathrm{H}), 1.42(\mathrm{~m}, 1 \mathrm{H}), 3.25(\mathrm{~m}, 1 \mathrm{H}), 3.38(\mathrm{~m} .1 \mathrm{H}), 3.60(\mathrm{~d}, 2 \mathrm{H}, J=4.4 \mathrm{~Hz}), 3.77(\mathrm{~d}$, $2 \mathrm{H}, J=4.5 \mathrm{~Hz}), 4.2(\mathrm{t}, 1 \mathrm{H}, J=6.3 \mathrm{~Hz}), 4.31(\mathrm{~d}, 2 \mathrm{H}, J=5.6 \mathrm{~Hz}), 4.99(\mathrm{~s}, 2 \mathrm{H}), 7.28$ $7.42(\mathrm{~m}, 10 \mathrm{H}), 7.65-7.68(\mathrm{~m}, 2 \mathrm{H}), 7.86-7.88(\mathrm{~m}, 3 \mathrm{H}) ;{ }^{13} \mathrm{C}$ NMR $(100 \mathrm{MHz}$ $\left.\mathrm{CDCl}_{3}\right): \delta 11.2,14.8,20.2,24.9,39.9,40.1,45.7,46.7,47.3,53.6,65.0,65.2$, $120.0,121.2,124.3,125.0,126.9,127.6,128.2,140.7,141.2,144.0,155.8,170.5$. 